\begin{tabular}{cc|c}
\hline Tar. Bil.Der. & Tarım Bilimleri Dergisi & Journal of Agricultural Sciences \\
& $\begin{array}{c}\text { Dergi web sayfası: } \\
\text { www.agri.ankara.edu.tr/dergi }\end{array}$ & $\begin{array}{c}\text { Journal homepage: } \\
\text { www.agri.ankara.edu.tr/journal }\end{array}$ \\
\hline
\end{tabular}

\title{
Yaşlanma Esnasında Soğan Tohumlarında Meydana Gelen Fizyolojik ve Biyokimyasal Değişimler
}

\author{
Mustafa DEMİRKAYA ${ }^{a}$, H. Özkan SIVRITEPE ${ }^{b}$ \\ ${ }^{a}$ Erciyes Üniversitesi, Safiye Çıkrıkçıŏlu Meslek Yüksekokulu, Bahçe Ziraatı Programı, Kayseri, TÜRKIYYE \\ ${ }^{b}$ Uludağ Üniversitesi, Ziraat Fakültesi, Bahçe Bitkileri Bölümü, Görükle Kampüsü, Bursa, TÜRKIYYE
}

\section{ESER BÍLGISI}

Araştırma Makalesi — Bitkisel Üretim

DOI: $10.1501 /$ Tarimbil_0000001162

Sorumlu Yazar: H. Özkan SIVRITEPE, e-posta: ozkan@uludag.edu.tr, Tel: +90(224) 2941474

Geliş tarihi: 24 Ağustos 2009, Düzeltmelerin gelişi: 16 Temmuz 2011, Kabul: 19 Temmuz 2011

\begin{abstract}
ÖZET
Bu çalışmada canlılı̆̆ını kısa sürede kaybeden soğan tohumlarında, farklı canlılık seviyelerinde ortaya çıkan bazı fizyolojik ve biyokimyasal değişimler incelenmiştir. Bu amaçla Akgün-12, Valencia ve TEG-502 çeşidi soğan tohumlarında \%95, 80, 60, 40 ve 20 canlılık seviyeleri kontrollü bozulma uygulamaları ile elde edilmiștir. Daha sonra bu canlılık seviyelerinde ortalama çimlenme süresi, elektriksel iletkenlik, toplam yă̆, toplam protein, çözülebilir protein, malondialdehit (MDA) ve katalaz aktivitesi ölçümleri yapılmıştır. Contes çeşidinde başlangıç canlılığ $\% 80$ olması nedeniyle, aynı ölçümler \%80, 60, 40 ve 20 canlılık seviyelerinde yapılmıştır. Yaşlanmayla birlikte, ortalama çimlenme süresi, elektriksel iletkenlik ve MDA içeriği artarken, toplam yağ, toplam protein, çözülebilir protein içeriği ve katalaz aktivitesinin azaldığ 1 tespit edilmiştir. Ayrıca, ortalama çimlenme süresi, MDA içeriği ve elektriksel iletkenliğin artması ve katalaz aktivitesinin azalması, tohum canlılığının bir eşik değer olarak belirlenen \%60 seviyesine ya da bunun altına düştüğ̈nde daha belirgin olmuştur.
\end{abstract}

Anahtar sözcükler: Allium cepa L.; Tohum; Kontrollü bozulma; Canlılık; Güç

\section{Physiological and Biochemical Changes Occur in Onion Seeds during Ageing}

\section{ARTICLE INFO}

Research Article — Crop Production

Corresponding author: H. Özkan SIVRITEPE, e-mail: ozkan@uludag.edu.tr, Tel: +90(224) 2941474

Received: 24 August 2009, Received in revised form: 16 July 2011, Accepted: 19 July 2011

\begin{abstract}
In this study, physiological and biochemical changes at different viability levels were investigated in onion seeds, which lose their viability in a short period of time. For this purpose 95, 80, 60, 40 and 20\% viability levels were obtained by controlled deterioration treatments in seeds of onion cvs. Akgün-12, Valencia and TEG-502. Subsequently, mean germination time, electrical conductivity, total lipid, total protein, soluble protein, malondialdehyde (MDA) and catalase activity measurements were conducted at these viability levels. Regarding
\end{abstract}


the seeds of cv. Contes, same measurements were conducted at 80, 60, 40 and 20\% viability levels since the initial seed viability was $80 \%$. Depending on seed ageing, as mean germination time, electrical conductivity and MDA content increased, total lipid, total protein, soluble protein contents and catalase activity decreased. Moreover, the increase in mean germination time, MDA content and electrical conductivity and also decrease in catalase activity were more evident when seed viability of each onion cultivar decreased $60 \%$ or below this level, which was determined as a threshold.

Keywords: Allium cepa L.; Seed; Controlled deterioration; Viability; Vigour

(C) Ankara Üniversitesi Ziraat Fakültesi

\section{Giriş}

Tohumlarda yaşlanma ile birlikte canlılık ve gücün azalmasina neden olan en önemli faktörlerden ikisi tohum nem kapsamı ve sicaklıktır (Basu 1995; McDonald 2004). Bu canlılık ve güç kayıpları tohum tür ve çeşitlerine göre değişmektedir. Tohum yaşlanmasının temel nedenleri olarak bugüne kadar çok sayıda hipotez ileri sürülmüştür. Bunlar; lipid peroksidasyonu, hücre membranlarının bozulması, enzimlerin yapılarındaki temel değişiklikler sonucu enzim azalması ve inaktivasyonu, proteinlerin azalması, genetik bozulma, toksik bileşiklerin birikimi, vb. olarak sayılabilir. Ancak, tohumlarda meydana gelen yaşlanmanın bu sebeplerden birkaçının birlikte oluşturduğu bir sonuç olduğu da açıktır (Coolbear 1995; Copeland \& McDonald 2001; McDonald 2004).

Tohumlarda yaşlanmanın nedeni olarak ileri sürülen hipotezlerden en çok kabul görenlerden biri, özellikle yağ içeriği yüksek olan tohumlarda meydana gelen lipid peroksidasyonudur (Perl et al 1987; Bailly et al 1996; Copeland \& McDonald 2001; Goel et al 2002; Goel \& Sheoran 2003). Serbest yağ kökleri, metabolik süreçler ve iyonize radyasyon gibi nedenlerle meydana gelen lipid peroksidasyonu, yüksek sicaklık ve oksijen konsantrasyonu ile artmaktadır (Copeland \& McDonald 2001). Çoklu doymamış yağ asitlerinin enzimatik bozulmasında ikincil bir ürün olarak bilinen malondialdehit (MDA), lipid peroksidasyonunun güvenilir bir ölçütü olarak kabul edilir (Li et al 2007).

Tohum yaşlanmasının temeli olarak bilinen en önemli hipotezlerden biri de, enzimlerin yapılarındaki temel değişiklikler sonucu enzim azalması ve inaktivasyonudur (Salama \& Pearce
1993; Basra \& Malik 1994; Copeland \& McDonald 2001; Goel et al 2002; Murthy et al 2003). Yaşlanmış tohumlarda katalaz, dehidrogenaz ve glutamik asit dekarboksilaz gibi enzimlerin aktivitesinde azalma meydana gelmektedir. Enzim aktivitesinin azalmas1, solunum potansiyelini ve ATP oluşumunu, dolayısıyla çimlenmede tohuma sağlanan besin miktarını düşürmektedir (Copeland \& McDonald 2001).

Hücre membranlarının bozulması, tohumlarda yaşlanmayı açıklayan diğer önemli bir hipotezdir ve yaşlanma esnasinda tohumdan sızan maddelerin elektriksel iletkenliğinde meydana gelen artışlar olarak ölçülebilir (Coolbear 1995).

Bu çalışmada ilk olarak, farklı soğan çeşitlerinin benzer nem kapsamlarındaki tohumlarının kontrollü bozulma uygulamalarına tabi tutularak, her çeşidin canlılık eğrisinin oluşturulması ve böylece yaşlanmaya olan eğiliminin belirlenmesi hedeflenmiştir. Ayrıca, soğan tohumlarında elde edilen farklı canlılık seviyelerinde yaşlanma esnasında meydana gelen çeşitli fizyolojik ve biyokimyasal değişimlerin incelenmesi amaçlanmıştır.

\section{Materyal ve Yöntem}

$\mathrm{Bu}$ araştırmada bitkisel materyal olarak, Yalova Atatürk Bahçe Kültürleri Merkez Araştırma Enstitüsü'nden temin edilen, Akgün-12 ile MayAgro Tohumculuk San. Tic. Ltd. Şti.'den temin edilen Valencia, TEG-502 ve Contes soğan çeşitlerine ait tohumlar kullanılmıştır. Uygulamalar öncesinde, farklı çeşitlere ait soğan tohumlarının başlangıç nem kapsamlarının birbirine mümkün olduğunca yakın olması amaçlanmıştır. Böylece değişik parametreler açısından, çeşitler arasında meydana gelecek olan 
farklılıkların nem kapsamından kaynaklanma olasılığı ortadan kaldırılmıştır. Tohumlarda nem düzeylerinin sabitlenebilmesi için her çeşit ayrı bir tepsiye konularak iyice yayılmış, $20^{\circ} \mathrm{C}$ 'de ve $\% 50 \pm 5$ oransal nemde 14 gün boyunca iklim dolabinda bekletildikten sonra tohumların nem kapsamları yaklaşık olarak \%8.4-8.5 arasında dengelenmiştir.

Nem kapsamı ve canlılığı bilinen tohumlar, cam kavanozlar içine konulmuş, kapakların ağzı sıkıca kapatılmış ve kavanozlar etiketlenmiştir. Kontrollü bozulma (yaşlandırma) uygulamaları $60 \pm 1^{\circ} \mathrm{C}^{\prime}$ ye ayarlanmış iklim dolabında yapılmıştır (Sivritepe \& Demirkaya 2002). Bu uygulamalardan sonra; Akgün-12, Valencia ve TEG-502 çeşidi soğan tohumlarında yaklaşık $\% 95,80,60,40$ ve 20 olmak üzere 5 farklı canlılık seviyesi tespit edilmiştir. Contes çeşidi soğan tohumlarında ise, başlangıç canlılığının $\% 80$ olması nedeniyle, yaklaşı $\% 80,60,40$ ve 20 olmak üzere 4 farklı canlılık seviyesi tespit edilmiş̧ir. Yukarıda verilen canlılık seviyeleri en çok \% 4'lük bir sapma ile elde edilmiştir.

Soğan tohumlarında nem kapsamı tayini, Uluslararası Tohum Deneme Birliği (International Seed Testing Association - ISTA) Kuralları'na uygun olarak, Düşük Sabit Sıcaklıktaki Fırın Yöntemi'ne göre yapılmıştır (ISTA 2005). Çimlendirme testi, 4 tekerrürden oluşan (her tekerrürde 50 tohum) toplam 200 tohumla, $20 \pm 1{ }^{\circ} \mathrm{C}$ 'de ve ISTA Kuralları'na bağlı kalınarak yapılmıştır (ISTA 2005). Tohum canlılığı, sayım sonunda yüzde çimlenme (normal çimlenen tohumların yüzdesi) olarak belirlenmiştir. Çimlendirme testleri, temin edilen tohumların başlangıçtaki canlılığını belirlemek ve yaşlandırma uygulamalarından sonra elde edilen canlılı̆̆ tohumlarında yapılan çimlendirme testlerinde 21 gün boyunca çimlenen tohumlar günlük olarak sayılmış ve elde edilen sonuçlardan Ellis \& Roberts (1981)'a göre ortalama çimlenme süresi hesaplanmıştır.

Tohumdan sizan maddelerin elektriksel iletkenliğinin ölçümü, 4 tekerrürlü olarak ve her bir tekerrürde 200 adet soğan tohumu tartıldıktan sonra $30^{\circ} \mathrm{C}^{\prime}$ de $80 \mathrm{~m} l$ saf suda 24 saat bekletilerek yapılmıştır (İlbi \& Eser 2004). Yağ tayini sokselat yöntemiyle yapılmıştır (Hart \& Fischer 1971). Tohumların protein içeriklerinde meydana gelen değişimleri belirlemek amacıyla, Kjeldal Yöntemi (Steubing 1965) kullanılmıştır. Malondialdehit (MDA) tayini Peever \& Higgins (1989)'e göre yapılmıştır. Çözülebilir protein içeriği Bradford (1976)'a göre tayin edilmiş, daha sonra enzim ekstraktının $1 \mathrm{ml}$ 'sinde $100 \mu \mathrm{g}$ çözülebilir protein olacak şekilde enzim ölçümü için süpernatant alınmış, katalaz aktivitesi Chance \& Maehly (1995)'e göre belirlenmiştir. Toplam yağ, toplam protein, MDA, çözülebilir protein ve katalaz analizleri her canlılık seviyesi için üç tekerrürlü olarak yapılmıştır.

Tesadüf parselleri deneme desenine uygun olarak elde edilen verilerin varyans analizleri "SSPS 13.0 for Windows" istatistik programında yapılmış, ortalamalar arasındaki farklılıklar 0.05 önemlilik seviyesinde LSD testine göre belirlenmiştir. Ayrıca yüzde olarak ifade edilen parametrelerde (toplam yağ ve toplam protein) verilerin istatistiksel analizi yapılmadan önce arcsin transformasyonu uygulanarak açı değerleri elde edilmiştir. Çizelgelerde her bir parametre için elde edilen ortalama değerlerin yanında \pm olarak standart hata değerleri de verilmiştir.

\section{Bulgular ve Tartışma}

Kontrollü bozulma uygulamalarından sonra yapılan çimlendirme testlerinden elde edilen veriler, her bir çeşit için belirli yaşlandırma sürelerine karşıllı gelen normal çimlenme oranları olarak ayrı seriler halinde bir grafik üzerine yerleştirilmiştir. Böylece her soğan çeşidine ait tohum gruplarından elde edilen canlılık eğrileri karşılaştırılmıştır (Şekil 1). Kontrollü bozulma uygulamaları, zamandaki artışa bağlı olarak her bir soğan çeşidinde tohum canlılığının azalmasına neden olmuştur. Tohum canlılığındaki en hızlı kayıplar Akgün-12 çeşidinde meydana gelmiştir. Bunu sirasiyla Contes, TEG-502 ve Valencia çeşitleri izlemiştir.

Ortalama çimlenme süreleri incelendiğinde; Akgün-12, Valencia, TEG-502 ve Contes soğan 


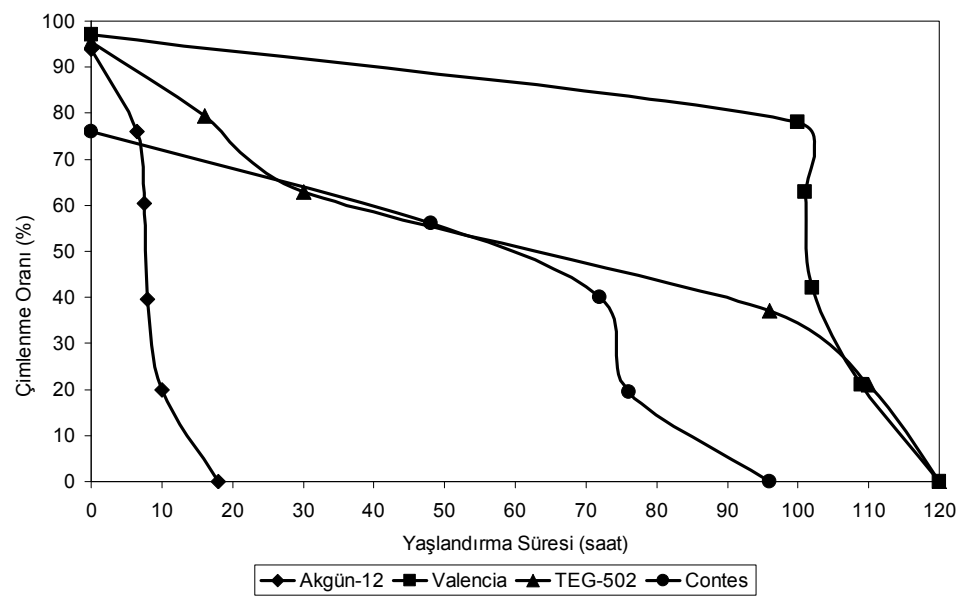

Şekil 1-Akgün-12, Valencia, TEG-502 ve Contes soğan çeşitlerinin tohumlarında yaşlandırma süresi ile canlılık kaybı arasındaki ilişki

Figure 1-Relationship between ageing period and loss of viability in seeds of onion cultivars Akgün-12, Valencia, TEG-502 and Contes

tohumlarında canlılık kaybı ile ortalama çimlenme sürelerinde meydana gelen artış tüm çeşitlerde önemli $(P<0.001)$ bulunmuşstur. Diğer bir deyişle, tohumların canlılığ ile birlikte gücü (vigoru) de azalmıştır (Çizelge 1). Daha önce bu ilişki Dell'Aquila (1987) tarafından detaylandırılmış ve ortalama çimlenme süresinin tohum yaşlanmasının incelenmesinde önemli bir kriter olduğu belirtilmiştir.

Farkl1 canl1l1k seviyelerinin, Akgün-12, Valencia, TEG-502 ve Contes soğan çeşitlerinin tohumlarında elektriksel iletkenlik değerlerindeki artışlar, yapılan istatistiksel analizler sonucu önemli $(P<0.01)$ bulunmuştur (Çizelge 2$)$. Ancak yaşlanma ile birlikte, sızan madde miktarının artışına paralel olarak, elektriksel iletkenlik değerlerindeki en yüksek artış Valencia çeşidinde görülmüştür. Bu sonuçlar Doijode (1990), Basra \& Malik (1994) ile İlbi \& Eser (2004)'in soğan tohumlarında canlılık ve güç kaybı ile tohumdan madde sızıntısındaki artış arasında pozitif bir ilişkinin olduğunu belirttikleri çalışmaları teyit etmiştir. Bu çalışmada elde ettiğimiz sonuçlar göstermektedir ki; soğan tohumlarında yaşlanma esnasında canlılıkta meydana gelen azalma ile ters orantılı olarak hücre membranlarının bozulma oranı artmaktadır. Böylece hücre membranları seçici geçirgenlik özelliğini kaybederek zamanla daha çok zarar görmekte ve böylece sitoplazmadan dışarı sızan maddelerin (şekerler, amino asitler, iyonlar, vs.) miktarlarında da artışlar meydana gelmektedir.

Akgün-12 ve Valencia soğan tohumlarında canlılık kaybı ile toplam yağ oranları azalmış, ancak bu düşüş istatistiksel olarak önemli olmamıştır $(P>0.05)$. Bu bulgular Perl et al (1987)'nin soğan tohumlarında yapmış olduğu çalışma ile paralellik göstermiştir. Öte yandan, TEG-502 ve Contes çeşitlerinde ise canlılık kaybı ile toplam yağ oranlarının azalması önemli $(P<0.001)$ bulunmuştur (Çizelge 3$)$. Bu sonuçlar ise, Hannan (1991)'ın soğan tohumlarında yaptığ çalışmalar ile uyum göstermiştir. Tohumların yaşlanmasına bağlı olarak toplam yağ oranlarında meydana gelen azalma genel bir eğilim olmakla birlikte, bu çalışmada genotipe ve yaşlanmanın karakterine bağlı olarak farklılıkların olabileceği de gösterilmiştir.

Soğan tohumlarında yaşlanma ile birlikte toplam protein oran1, Akgün-12, Valencia, TEG502 ve Contes çeşitlerinde azalmış; ancak Contes çeşidindeki azalma istatistiksel olarak önemsiz $(P>0.05) \quad$ bulunmuştur (Çizelge 4). 
Çizelge 1-Dört soğan çeşidinin tohumlarında yaşlanma ile ortalama çimlenme süresinde meydana gelen değişimler

Table 1-Changes occur in mean germination time due to ageing in seeds offour onion cultivars

\begin{tabular}{crrrr}
\hline Canlllı, & \multicolumn{4}{c}{ Ortalama Çimlenme Süresi, Gün } \\
\cline { 2 - 5 }$\%$ & Akgün-12 & Valencia & \multicolumn{1}{c}{ TEG-502 } & \multicolumn{1}{c}{ Contes } \\
\hline 95 & $4.8 \pm 0.099 \mathrm{c} *$ & $5.5 \pm 0.043 \mathrm{~d}$ & $5.3 \pm 0.050 \mathrm{~d}$ & \\
80 & $8.6 \pm 0.040 \mathrm{~b}$ & $6.2 \pm 0.208 \mathrm{c}$ & $5.7 \pm 0.209 \mathrm{~d}$ & $6.5 \pm 0.187 \mathrm{~b}$ \\
60 & $9.3 \pm 0.473 \mathrm{~b}$ & $7.7 \pm 0.121 \mathrm{~b}$ & $9.5 \pm 0.123 \mathrm{c}$ & $6.6 \pm 0.215 \mathrm{~b}$ \\
40 & $9.7 \pm 0.182 \mathrm{~b}$ & $10.0 \pm 0.231 \mathrm{a}$ & $10.3 \pm 0.324 \mathrm{~b}$ & $9.7 \pm 0.125 \mathrm{a}$ \\
20 & $11.6 \pm 0.818 \mathrm{a}$ & $10.0 \pm 0.196 \mathrm{a}$ & $13.6 \pm 0.375 \mathrm{a}$ & $10.1 \pm 0.091 \mathrm{a}$ \\
\hline$P$ & 0.001 & 0.001 & 0.001 & 0.001 \\
\hline
\end{tabular}

* Farklı harfler uygulama grupları arasındaki farklılıkları göstermektedir $(P<0.05)$

Çizelge 2- Dört soğan çeşidinin tohumlarında yaşlanma ile elektriksel iletkenlikte meydana gelen değişimler

Table 2-Changes occur in electrical conductivity due to ageing in seeds of four onion cultivars

\begin{tabular}{ccccc}
\hline Canlllık, & \multicolumn{4}{c}{ Elektriksel Iletkenlik, $\mu S \mathrm{~cm}^{-1} \mathrm{~g}^{-1}$} \\
\cline { 2 - 5 }$\%$ & Akgün-12 & Valencia & TEG-502 & Contes \\
\hline 95 & $145.2 \pm 1.657 \mathrm{c} *$ & $107.6 \pm 1.172 \mathrm{~d}$ & $218.7 \pm 1.418 \mathrm{~b}$ & \\
80 & $149.2 \pm 1.299 \mathrm{c}$ & $122.0 \pm 0.452 \mathrm{c}$ & $223.9 \pm 3.142 \mathrm{~b}$ & $192.5 \pm 2.681 \mathrm{c}$ \\
60 & $160.3 \pm 1.480 \mathrm{~b}$ & $123.1 \pm 2.178 \mathrm{c}$ & $240.3 \pm 4.460 \mathrm{a}$ & $199.9 \pm 2.187 \mathrm{c}$ \\
40 & $165.0 \pm 2.747 \mathrm{ab}$ & $135.3 \pm 2.067 \mathrm{~b}$ & $240.2 \pm 7.363 \mathrm{a}$ & $216.0 \pm 2.123 \mathrm{~b}$ \\
20 & $167.7 \pm 0.102 \mathrm{a}$ & $160.5 \pm 5.172 \mathrm{a}$ & $249.1 \pm 2.873 \mathrm{a}$ & $228.4 \pm 2.433 \mathrm{a}$ \\
\hline$P$ & 0.001 & 0.001 & 0.003 & 0.001 \\
\hline
\end{tabular}

* Farklı harfler uygulama grupları arasındaki farklılıkları göstermektedir $(P<0.05)$

Çizelge 3- Dört soğan çeşidinin tohumlarında yaşlanma ile toplam yağ oranında meydana gelen değişimler

Table 3-Changes occur in total lipid rate due to ageing in seeds of four onion cultivars

\begin{tabular}{ccccc}
\hline Canlılık, & \multicolumn{4}{c}{ Toplam Yağ Oranı, \% } \\
\cline { 2 - 5 }$\%$ & Akgün-12 & Valencia & TEG-502 & Contes \\
\hline 95 & $24.5 \pm 0.321$ & $23.8 \pm 0.152$ & $24.6 \pm 0.102 \mathrm{a}^{*}$ & \\
80 & $24.3 \pm 0.412$ & $23.6 \pm 0.302$ & $24.5 \pm 0.120 \mathrm{a}$ & $23.7 \pm 0.169 \mathrm{a}$ \\
60 & $24.3 \pm 0.384$ & $23.6 \pm 0.194$ & $24.3 \pm 0.170 \mathrm{a}$ & $23.2 \pm 0.126 \mathrm{~b}$ \\
40 & $24.1 \pm 0.267$ & $23.5 \pm 0.115$ & $23.4 \pm 0.047 \mathrm{~b}$ & $23.1 \pm 0.084 \mathrm{~b}$ \\
20 & $23.8 \pm 0.210$ & $23.3 \pm 0.142$ & $23.3 \pm 0.069 \mathrm{~b}$ & $22.6 \pm 0.024 \mathrm{c}$ \\
\hline$P$ & 0.649 & 0.604 & 0.001 & 0.001 \\
\hline
\end{tabular}

* Farklı harfler uygulama grupları arasındaki farklı1ıkları göstermektedir $(P<0.05)$

Çizelge 4- Dört soğan çeşidinin tohumlarında yaşlanma ile toplam protein oranında meydana gelen değişimler

Table 4-Changes occur in total protein rate due to ageing in seeds of four onion cultivars

\begin{tabular}{ccccc}
\hline Canlllik, & \multicolumn{4}{c}{ Toplam Protein Oranl, \% } \\
\cline { 2 - 5 }$\%$ & Akgün-12 & Valencia & TEG-502 & Contes \\
\hline 95 & $20.8 \pm 0.015 \mathrm{a} *$ & $22.1 \pm 0.023 \mathrm{a}$ & $21.7 \pm 0.129 \mathrm{a}$ & \\
80 & $20.7 \pm 0.024 \mathrm{ab}$ & $22.1 \pm 0.046 \mathrm{a}$ & $21.6 \pm 0.041 \mathrm{a}$ & $23.9 \pm 0.257$ \\
60 & $20.6 \pm 0.033 \mathrm{~b}$ & $21.8 \pm 0.053 \mathrm{~b}$ & $21.5 \pm 0.042 \mathrm{a}$ & $23.8 \pm 0.254$ \\
40 & $20.3 \pm 0.045 \mathrm{c}$ & $21.5 \pm 0.119 \mathrm{c}$ & $21.2 \pm 0.064 \mathrm{~b}$ & $23.6 \pm 0.262$ \\
20 & $20.0 \pm 0.060 \mathrm{~d}$ & $21.2 \pm 0.092 \mathrm{~d}$ & $21.1 \pm 0.033 \mathrm{~b}$ & $23.3 \pm 0.194$ \\
\hline$P$ & 0.001 & 0.001 & 0.002 & 0.373 \\
\hline
\end{tabular}

* Farklı harfler uygulama grupları arasındaki farklılıkları göstermektedir $(P<0.05)$ 
Çalışmamızdan elde edilen sonuçlar, Coolbear (1995) ve McDonald (2004) ile paralellik göstermiştir. Araştırmacılar, yaşlanmayla tohumlarda meydana gelen canlılık kaybının proteinlerdeki azalmayla ilgili olabileceğini belirtmişlerdir.

Soğan tohumlarında farklı canlılık seviyelerindeki çözülebilir protein içerikleri incelendiğinde, her bir çeșitte canlılık düştükçe çözülebilir protein içeriği istatistiksel olarak önemli düzeyde $(P<0.05)$ azalmıştır (Çizelge 5). Bu bulgular, Halder \& Gupta (1980)'nın ayçiçeği tohumlarında yapmış oldukları çalışmaları teyit etmiştir. Ayrıca Blackman \& Leopold (1993), tohum yaşlanmasının çözülebilir protein içeriğinde azalmaya neden olduğunu belirtmiştir. Canlılık seviyeleri düştükçe MDA içeriği artmıştır. MDA içeriğindeki artış özellikle canlılık $\% 60$ ya da bu seviyenin altına düştüğünde daha hızlı olmuştur. $\mathrm{Bu}$ artışlar bütün çeşitlerde istatistiksel olarak önemli $(P<0.05)$ bulunmuştur (Çizelge 6). Birçok araştırıcıya göre (Perl et al
1987; Thompson et al 1987; Smith \& Berjak 1995; Bailly et al 1996; Goel et al 2002); özellikle yağlı tohumlarda yaşlanmanın en önemli nedeni lipid peroksidasyonu ve buna bağlı olarak gelişen reaksiyonlardır. Çalışmamızdan elde edilen sonuçlar, özellikle Salama \& Pearce (1993) ile Basra \& Malik (1994)'in soğan tohumlarında yaptığı çalışmalarla paralellik göstermiştir.

Genel bir eğilim olarak, tohum canlılığı azaldıkça katalaz aktivitesi de azalmıştır. Katalaz aktivitesindeki azalmalar özellikle canlılık \%60 ya da altına düştüğünde daha hızlı olmuştur. $\mathrm{Bu}$ azalma tüm çeşitlerde istatistiksel olarak önemli $(P<0.001)$ bulunmuştur. Katalaz aktivitesindeki en hızlı azalma, canlılığını ve gücünü en çabuk kaybeden Akgün-12 çeşidinde gerçekleşmiştir (Çizelge 7). Bu sonuçlar, Basra \& Malik (1994)'in soğan tohumlarında, Bailly et al (1996)'nın ayçiçeği tohumlarında, Goel et al (2002)'nin pamuk tohumlarında ve Zeng et al (2004)'ün hıyar tohumlarında yaptıkları çalışmalarla uyum halindedir.

Çizelge 5- Dört soğan çeşidinin tohumlarında yaşlanma ile çözülebilir protein içeriğinde meydana gelen değişimler

Table 5-Changes occur in soluble protein content due to ageing in seeds of four onion cultivars

\begin{tabular}{ccccc}
\hline Canlılık, & \multicolumn{4}{c}{ Çözülebilir Protein, $m g g^{-1}$ taze ağırlk } \\
\cline { 2 - 5 }$\%$ & Akgün-12 & Valencia & TEG-502 & Contes \\
\hline 95 & $15.3 \pm 0.205 \mathrm{a}^{*}$ & $15.2 \pm 0.203 \mathrm{a}$ & $15.4 \pm 0.152 \mathrm{a}$ & \\
80 & $14.3 \pm 0.365 \mathrm{a}$ & $15.3 \pm 0.266 \mathrm{a}$ & $15.0 \pm 0.112 \mathrm{ab}$ & $12.3 \pm 0.199 \mathrm{a}$ \\
60 & $10.7 \pm 0.191 \mathrm{c}$ & $11.0 \pm 0.465 \mathrm{~b}$ & $13.7 \pm 0.203 \mathrm{c}$ & $11.5 \pm 0.469 \mathrm{a}$ \\
40 & $12.5 \pm 0.591 \mathrm{~b}$ & $11.5 \pm 0.269 \mathrm{~b}$ & $14.9 \pm 0.145 \mathrm{~b}$ & $12.1 \pm 0.179 \mathrm{a}$ \\
20 & $11.3 \pm 0.430 \mathrm{bc}$ & $11.2 \pm 0.306 \mathrm{~b}$ & $14.6 \pm 0.156 \mathrm{~b}$ & $10.2 \pm 0.112 \mathrm{~b}$ \\
\hline$P$ & 0.001 & 0.001 & 0.001 & 0.003 \\
\hline
\end{tabular}

* Farklı harfler uygulama grupları arasındaki farklılıkları göstermektedir $(P<0.05)$

Çizelge 6- Dört soğan çeşidinin tohumlarında yaşlanma ile MDA içeriğinde meydana gelen değișimler Table 6-Changes occur in MDA content due to ageing in seeds of four onion cultivars

\begin{tabular}{ccccc}
\hline Canlılık, & \multicolumn{4}{c}{ MDA, $\mu$ mol g ${ }^{-1}$ taze ağırlık } \\
\cline { 2 - 5 }$\%$ & Akgün-12 & Valencia & TEG-502 & Contes \\
\hline 95 & $24.6 \pm 0.244 \mathrm{c}^{*}$ & $20.3 \pm 0.475 \mathrm{c}$ & $23.8 \pm 0.362 \mathrm{c}$ & \\
80 & $24.5 \pm 0.165 \mathrm{c}$ & $21.3 \pm 0.896 \mathrm{bc}$ & $24.1 \pm 1.777 \mathrm{c}$ & $24.1 \pm 0.150 \mathrm{c}$ \\
60 & $29.0 \pm 0.219 \mathrm{~b}$ & $22.4 \pm 0.428 \mathrm{abc}$ & $28.5 \pm 1.177 \mathrm{~b}$ & $27.1 \pm 0.101 \mathrm{~b}$ \\
40 & $28.7 \pm 0.587 \mathrm{~b}$ & $23.2 \pm 0.839 \mathrm{ab}$ & $28.8 \pm 0.792 \mathrm{~b}$ & $27.9 \pm 0.404 \mathrm{ab}$ \\
20 & $30.4 \pm 0.188 \mathrm{a}$ & $24.0 \pm 0.637 \mathrm{a}$ & $33.7 \pm 1.892 \mathrm{a}$ & $29.0 \pm 0.671 \mathrm{a}$ \\
\hline$P$ & 0.001 & 0.021 & 0.003 & 0.001 \\
\hline
\end{tabular}

* Farklı harfler uygulama grupları arasındaki farklılıkları göstermektedir $(P<0.05)$ 
Çizelge 7- Dört soğan çeşidinin tohumlarında yaşlanma ile katalaz aktivitesinde meydana gelen değişimler

Table 7-Changes occur in catalase activity due to ageing in seeds of four onion cultivars

\begin{tabular}{ccccc}
\hline Canlılık, & \multicolumn{4}{c}{ Katalaz, $\mathrm{nmol} \mathrm{H}_{2} \mathrm{O}_{2}$ dak $^{-1} \mathrm{mg}^{-1}$ protein } \\
\cline { 2 - 5 }$\%$ & Akgün-12 & Valencia & TEG-502 & Contes \\
\hline 95 & $70.2 \pm 0.693 \mathrm{a}^{*}$ & $48.4 \pm 0.318 \mathrm{a}$ & $46.6 \pm 0.384 \mathrm{a}$ & \\
80 & $69.3 \pm 0.441 \mathrm{a}$ & $48.0 \pm 0.348 \mathrm{a}$ & $45.3 \pm 0.371 \mathrm{ab}$ & $61.4 \pm 0.833 \mathrm{a}$ \\
60 & $63.4 \pm 0.664 \mathrm{~b}$ & $47.4 \pm 0.498 \mathrm{a}$ & $44.3 \pm 0.265 \mathrm{~b}$ & $50.6 \pm 0.689 \mathrm{~b}$ \\
40 & $51.5 \pm 0.751 \mathrm{c}$ & $43.2 \pm 0.285 \mathrm{~b}$ & $41.5 \pm 0.882 \mathrm{c}$ & $50.4 \pm 0.503 \mathrm{~b}$ \\
20 & $50.7 \pm 0.786 \mathrm{c}$ & $40.6 \pm 0.611 \mathrm{c}$ & $39.3 \pm 0.437 \mathrm{~d}$ & $49.4 \pm 0.252 \mathrm{~b}$ \\
\hline$P$ & 0.001 & 0.001 & 0.001 & 0.001 \\
\hline
\end{tabular}

* Farklı harfler uygulama grupları arasındaki farklılıkları göstermektedir $(P<0.05)$

\section{Sonuçlar}

$\mathrm{Bu}$ çalışmada yaşlanma ile birlikte dört farklı soğan çeşidinde, ortalama çimlenme süresi, elektriksel iletkenlik ve lipid peroksidasyonu (MDA) artmış, toplam yağ ve protein oranları, çözülebilir protein içeriği ve katalaz enzim aktivitesi azalmıştır. Ayrıca, ortalama çimlenme süresi, MDA içeriği ve elektriksel iletkenliğin artması ve katalaz aktivitesinin azalması, tohum canlılığının bir eşik değer olarak belirlenen $\% 60$ seviyesine ya da bunun altına düştüğünde daha belirgin olmuştur. Diğer bir deyişle, çeşitli fizyolojik ve biyokimyasal parametreler açısından $\%$ canlılık seviyesi, yaşlanan soğan tohumlarında kritik bir eşik noktasını işaret etmektedir. Tohum canlılı̆g 1 ve gücü bu seviyeden itibaren daha belirgin olarak azalmakta ve bozulma hızlanmaktadır.

Çalışmadan elde edilen sonuçlar, Blackman \& Leopold (1993)'un geliştirmiş oldukları soğan tohumlarında yaşlanma modeli ile de paralellik göstermiştir. Burada soğan tohumlarında yaşlanma ile birlikte proteinlerin bozulacağı veya parçalanacağı, enzimlerin inaktif hale geleceği, fosfolipid ve depo lipidlerinin parçalanacağı, membran geçirgenliğinin artacağı ve lipid peroksidasyonunun artacağı belirtilmektedir. Çalışma sonuçlarımız bu tespitleri teyit etmiştir. Bundan sonra yapılacak çalışmalarda, antioksidan enzimlerden katalaz aktivitesinin yanısıra süperoksit dismutaz ve glutatyon redüktaz ile serbest radikal üretiminde rol oynayan lipoksigenaz gibi enzimlerde meydana gelen değişimlerin incelenmesi yerinde olacaktır.
Ayrıca, bu değişimlerin tohum canlılığı ve gücü ile etkileşimleri de araştırılmalıdır.

\section{Kaynaklar}

Bailly C, Benamar A, Corbineau F \& Côme D (1996). Changes in malondialdehyde content and in superoxide dismutase, catalase and glutathione reductase activities in sunflower seeds as related to deterioration during accelerated ageing. Physiologia Plantarum 97: 104-110

Basra B S \& Malik C P (1994). Amelioration of the effects of ageing in onion seeds. Biologia Plantarum 36(3): 365-371

Basu R N (1995). Seed viability. In: A S Basra (Ed.), Seed quality: Basic mechanisms and agricultural implications, Food Products Press, New York, pp. $1-44$

Blackman S \& Leopold A C (1993). Chemical and Physical Factors in Seed Deterioration, Basic and Applied Aspects of Seed Biology In: Proceedings of the IVth International Workshop on Seeds, Vol. 3: 731-737, 20-24 July 1992, France

Bradford M M (1976). A rapid and sensitive method for the quantification of micrograms quantities of protein utilizing the principle of protein-dye binding. Analytical Biochemistry 72:248-254

Chance B \& Maehly A C (1995). Assay of Catalases and Peroksidases. Methods in Enzymology. Vol. 2, pp. $764-817$

Coolbear P (1995). Mechanisms of seed deterioration. In: A S Basra (Ed.) Seed quality: Basic mechanisms and agricultural implications, Food Products Press, New York, pp. 223-277

Copeland L O \& McDonald M B (2001). Principles of Seed Science and Technology. Kluwer Academic Publishers, Massachusetts, USA

Dell'Aquila A (1987). Mean germination time as a 
monitor of the seed ageing. Plant Physiology and Biochemistry 25(6): 761-768

Doijode S D (1990). Solute leakage in relation to loss of seed viability on accelerated ageing in different onion cultivars. Indian Journal of Plant Physiology 33: $54-57$

Ellis R H \& Roberts E H (1981). The quantification of aging and survival in orthodox seeds. Seed Science \& Technology 9: 373-409

Goel A, \& Sheoran I S (2003). Lipid peroxidation and peroxide-scavenging enzymes in cotton seeds under natural ageing. Biologia Plantarum 46:429-434

Goel A, Goel A K \& Sheoran I S (2002). Changes in oxidative stress enzymes during artificial ageing in cotton (Gossypium hirsutum L.) seeds. Journal of Plant Physiology 160: 1093-1100

Halder S \& Gupta K (1980). Effect of storage of sunflower seeds in high and low relative humidity on solute leaching and internal biochemical changes. Seed Science \& Technology 8: 317-321

Hannan R M (1991). Analysis of lipids in ageing seed using capillary supercritical fluid cromatography. Journal of Cromatography 54: 393-401

Hart F L \& Fischer H J (1971). Modern Analysis, Ger. Verlag, s. 17

ISTA (2005). International Rules for Seed Testing. Edition 2005. International Seed Testing Association. Bassersdorf, Switzerland

İlbi H \& Eser B (2004). Soğan tohumlarında yaşlanma ve fosfolipidlerdeki değişimler. V. Sebze Tarımı Sempozyumu. Bildiriler: 51-57. 21-24 Eylül 2004, Çanakkale

Li J, Zhang Y, Yu Z, Wang Y, Yang Y, Liu Z, Jiang J, Song M \& Wu Y (2007). Superior storage stability in low lipoxygenase maize varieties. Journal of Stored Products Research 43: 530-534

McDonald M B (2004). Orthodox seed deterioration and its repair. In: R L Benech-Arnold and R A Sanchez (Eds.), Handbook of seed physiology: Applications to agriculture, Food Products Press, New York, pp. 273-304

Murthy U M N, Kumar P P \& Sun W Q (2003). Mechanisms of seed ageing under different storage conditions for Vigna radiata (L.) Wilczek: Lipid peroxidation, sugar hydrolysis, Maillard reactions and their relationship to glass state transition. Journal of Experimental Botany 54: 1057-1067

Peever T L \& Higgins V J (1989). Electrolyte leakage, lipoxigenase and lipid peroxidation induced in tomato leaf tissue by specific and non-specific elicitors from Cladosporium fulvum. Plant Physiology 90: 867-875

Perl M, Yaniv Z \& Feder Z (1987). The effect of natural and accelerated ageing on the lipid content and the fatty acid composition of seeds. Acta Horticulturae 215: 51-66

Salama A M \& Pearce R G (1993). Ageing of cucumber and onion seeds: Phospholipase d, lipoxygenase activity and changes in phospholipid content. Journal of Experimental Botany 44: 1253-1265

Sivritepe H Ö \& Demirkaya M (2002). The effects of post-storage hydration treatments on viability of onion seeds. Acta Horticulturae 579: 215-219

Smith M T \& Berjak P (1995). Deteriorative changes associated with the loss of viability of stored desiccation tolerant and desiccation sensitive seeds. In: J Kigel \& G Galili (Eds.), Seed development and germination, New York, pp. 701-746

Steubing L (1965). Pflanzenökologisches Praktikum. Berlin-Hamburg: Parey

Thompson J E, Legge R L \& Barber R F (1987). The role of free radicals in senescence and wounding. New Phytologist 105: 317-344

Zeng X Y, Chen R Z, Fu J R \& Zhang X W (2004). The effects of water content during storage on physiological activity of cucumber. Plant Cell Preview (Published online May 21, 2004) 